\title{
SYRIAN CONFLICT AND THE ECONOMIC DEVELOPMENT: DID THE ECONOMIC INDICATORS PREDICT THE CONFLICT?
}

\author{
Ahmet Yulmaz ATA ${ }^{1}$ \\ Mohamed ABDULKARIM
}

\begin{abstract}
This paper aims at exploring whether the economic development indicators could have predicted the conflict in Syria in 2011. To evaluate the role of economic development in stabilizing the society, this paper analyses the available historical economic development indicators for the Syrian economy before the conflict in 2011. Reviewing the available official statistics about aforementioned indicators and benchmarking them against middle-income countries reveal that the annual growth in gross domestic product $(G D P)$ per capita, the government expenditure, inflation rate, unemployment rate, and human development index (HDI) were at alarming levels before 2011. This paves the way to the 2011 conflict in Syria.
\end{abstract}

Keywords: Economic Development, Economic Growth, Syria.

Jel Classification: E66, H11, O11, O43

\section{SURIYYE'DEKİ ÇATIŞMALAR VE EKONOMIK KALKINMA: EKONOMIKK GÖSTERGELER ÇATIŞMAYI ÖNGÖRMEYE YARDIMCI OLABİLIR MIYDI??}

$\ddot{O_{z}}$

Bu makale, ekonomik kalkınma göstergeleri üzerinden 2011'de Suriye'de başlayan çatışmaların tahmin edilip edilemeyeceğini araştırmayı amaçlamaktadır. Bu makale, ekonomik kalkınmanın toplumu istikrara kavuşturmadaki rolünü değerlendirmek için 2011'deki çatışmadan önce Suriye ekonomisinin mevcut tarihsel ekonomik kalkınma göstergelerini analiz etmektedir. Bahsedilen bu göstergelerle ilgili resmi istatistiklerin gözden geçirilmesi ve orta gelirli ülkelerle kıyaslanması, kişi başına düşen gayri safi yurtiçi hasıla (GSYH), hükümet harcamalarl, enflasyon oranı, işsizlik oranı ve insani gelişme endeksindeki (IGE) yıllık büyümenin iki 2011'den önce endişe verici seviyelerde olduğunu ortaya koymaktadır. Sonuç olarak, incelenen bütün bu ekonomik kalkınma göstergeleri çatışmayı öngörmeye yardımcı olmaktadır.

Anahtar Kelimeler: Ekonomik Kalkınma, Ekonomik Büyüme, Suriye.

Jel Sinıflandırılmast: E66, H11, O11, O43

\footnotetext{
${ }^{1}$ Prof. Dr., Kahramanmaraş Sütçü İmam Üniversitesi, yilmazata75@gmail.com, ORCID ID: https:Ilorcid.org/0000-0001-5928-8801 ${ }^{2}$ Doktora Öğrencisi, Kahramanmaraş Sütçü İmam Üniversitesi, mam181984@gmail.com, ORCID ID: https:Ilorcid.org/0000-00019364-2595.

Attf/To Cite: Ata, A.Y., \& Abdulkarim, M. (2021). Syrian Conflict and the Economic Development: Did the Economic Indicators Predict the Conflict? Journal of Economics and Research, 2(2), 1-16.
} 


\section{INTRODUCTION}

Economic Development is the process of producing wealth, wellbeing, and improving the community. So, it is an investment in developing the society and empowering it to achieve prosperity and improve the society's quality of life. Furthermore, economic development refers to a concerted effort and process through which a government, regulatory authorities and institutions improve their people's social, political, and economic wellbeing (Ivic, 2018:55: 56). In this context, economic development is concerned with creating wealth in a well-invested economy from which community benefits such that prosperity and improved living standards are realized. Economic development seeks to create opportunities and provide enough income for the local labor force and achieve proper economic growth (Nafziger, 2006:15).

Economic growth refers to the progressive increase in real national income and goods/services produced in a country over a specified period (Nafziger, 2006:15). Put differently, economic development describes the overall increase and improvement in living standards, quality of life and the ability to create economic growth (Stockwell, 1960:419). Economic development measures the qualitative aspect of a nation's progress through various models such as life-expectancy, human development and literacy levels (Liu, 2016; Ivic, 2015:61).

Having said that, the abovementioned definitions critically reveal the significance of economic development and its impact on society. The most significant social contributors to economic development include favorable healthcare, education, nutrition, equal income distribution and life-expectancy (Liu, 2016). Further, the alleviation of poverty levels is also an important social indicator that characterizes economic development (Ivic, 2018:61). To sum up, economic development is purely concerned with creating wealth to guarantee exceptional community benefits and outcomes. Also, it needs a remarkable effort to allocate the resources and efficiently use them to achieve the necessary income which improves the quality of life for the societies. This effort is not personal but rather it requires organized and systemized efforts to best allocate resources. Thus, economic development is a mutual responsibility of governments and societies to achieve the goals outlined by the economic development theories accordingly.

Acemoglu and Robinson (2013) studied why Egyptians protested their political regime in 2011. They pointed out that Egyptians have protested injustice, low standards of education, low standards of services provided by the state, corruption, and inequality. They quoted a tweet to Mohamed El-Baradei, a famous politician in Egypt, which is "Tunisia: lot of oppression + lack of social justice + ignoring the channels of peaceful change $=$ a time bomb." That statement may explain what motivated Arabs to protest against their regimes. On the other hand, Acemoglu and Robinson (2013) highlighted that Egyptians and Tunisians think that the lack of political rights is the leading cause of economic problems. Therefore, it was evident that protesters thoroughly think that political reasons lie at the root of these problems. All economic obstacles Egyptians and Tunisians faced are originated from the monopolization of political power by a small elite group. Moreover, Egyptians strongly believe that changing or improving the current economic and social situation starts from enhancing political rights and allowing young people to participate in the state's decisionmaking process. In the same vein, there is a belief between the Syrian people that the reason for the conflict can be attributed to political issues.

Thus, this work aims at assessing whether the governments' economic performance plays a role in societies stability sampling the Syrian conflict as a case study. More specifically, this paper tries to analyze if economic factors played a role in this conflict by 
surveying different economic indicators. Consequently, this paper will continue as follows. Next section will review the economic development and societies stability. Furthermore, section three will study different economic development indicators. Section four reviews the economic development in Syria before the conflict while section five concludes.

\section{THE ECONOMIC DEVELOPMENT INDICATORS}

Different indicators are used to recognize a specific country's economic development level in a specific period. These indicators help to draw inferences about the level of development in a country or to benchmark against other countries or different periods. Besides, these indicators help in planning a better economic development. This section describes different elements of the economic development from quantitative wise.

\subsection{Economic Growth Rate}

The GDP growth rate is the most important measure for assessing economic actors performing in general (Nafziger, 2006:72). Economic growth rate is defined as the percentage increase in the market value of production (goods and services) generated by an economy over time. Furthermore, economic growth is induced, in the short run, by a rise in aggregate demand (AD) without a corresponding increase in aggregate supply (AS). If the economy is capable, then perhaps a greater aggregate output would be triggered by a rise in $\mathrm{AD}$ (Mankiw, 2013:304). In the long run, the economic growth rate is measured by calculating the real GDP, i.e. the changes in GDP over years, based on base year prices. An example would be comparing the growth rate of 2020 with its counter in 2019 based on the prices of 2010. Thus, growth rate in GDP per capita in fixed prices should be calculated to be able to inspect the real growth (Berber, 2015:18).

\subsection{GDP Per Capita}

GDP per capita refers to a metric that presents a country's economic output per person The GDP per capita metric is still widely considered as a main indicator of economic performance in addition to standards of living improvement over time (Nolan et al., 2016:2).

The GDP growth per capita analyses a country's prosperity based on its economic growth, thus reflecting the improvements in country's wealth. GDP per capita, also, describes the country's economic productivity. It reflects the growth of the domestic income in line with the growth in population. However, the GDP per capita sometimes does not reflect the increase in the development factors other than income (Mankiw, 2013: 594). Some countries may have a small population and high income. This means that the GDP per capita for these countries may trend to stable growth in line with population growth without any real improvements in other economic or social factors. Besides, the population growth affects the GDP per capita. A country's income could grow at a constant rate but its population grows faster than its GDP which translates to a lower per capita GDP growth. This reduction is not a critical issue for most developed economies. However, countries with low income can have rapidly increasing populations with little GDP growth, resulting in a steady erosion of living standards (Mankiw, 2013:226-229).

Moreover, analyzing and monitoring the GDP per capita helps predict some important reactions or effects of the economy. One of these effects is when the development of GDP per capita reduces the negative effects of inequality of income distribution in a specific country (Brueckner et al., 2014: 18-19). Consequently, the GDP per capita is 
positively related to aggregate price levels, which means that the price levels are expected to rise when there is an increase in GDP per capita (Cravino and Haltenhof, 2017: 2).

\subsection{Welfare Level}

Gross Domestic Product (GDP) has been reviewed for being a weak indicator of welfare because it only measures the economic activities but ignores inequalities in income and wealth distribution, destruction of the natural environment, longevity or the quality of social relations. While the real GDP is considered as a main indicator to the economic welfare, the standards of living are also affected by health care levels, education, and environmental conditions including pollution and congestion. When judging the financial welfare of a society, standards of living variables are essential determinants (Aitken, 2019:1; Stockhammer et al., 1997: 19). For instance, real income affects the potential consumption while unemployment is considered a critical cost both economically and socially (Mankiw, 2013: 196; 284). Nevertheless, other factors such as health care, education opportunities, quality of education, health care, purchasing power, job satisfaction, etc should not be ignored (Nafziger,2006: 10; 30)

The critical issue is that the factors which decision-makers use to measure the economic performance would strongly influence their policies. Accordingly, if economic and social performance measurements were misdefined, this could lead to inefficient economic and social policy choices (Aitken, 2019: 14). Aitkrn (2019), though, pointed out that most of the economic welfare measures studied are short- term, and frequently measure flows rather than stocks.

\subsection{Cross Country Comparison}

Cross-country comparison is defined as a method of studying social facts through testing the similarities and differences between data gathered from more than one country. A trend analysis determines whether cross-country comparison is more effective method to be used than case studies. Interestingly, cross-country analysis supports the research (i.e. selection of countries) to examine and explore the causes (Smith, 2001: 157-160).

Moreover, the cross-country comparison's insights are very useful to policymakers. It is an advantageous indicator when assessing how the applied polices perform. Although cross-country comparison is helpful, it is highly recommended to use systemic models which distinguish between specifications of each variable to avoid the heterogeneity problem (Son, 2009:267).

\subsection{Human Development Index (HDI)}

The Human Development Index (HDI) is a summary measure of average achievement in key dimensions of human development: a long and healthy life, being knowledgeable, and have a decent standard of living. The HDI is the geometric mean of normalized indices for each of the three dimensions (UNDP, 2020). The HDI has been released for the first time since United Nation Development Program (UNDP) creation in 1990.

Further, the HDI in a nation is determined through life expectancy, gross national income (GNI) per capita, quality of education, health provision and adult education. HDI could also be utilized to challenge regional policy decisions and to question how diverse the 
society is (hdr.undp.org). These components will generate discussion about public policy objectives and the importance of considering this index in planning policies.

Remarkably, HDI's structure was criticized in the literature. For instance, HDI underestimates the role of income and its differentials ignoring that higher income would improve people's choices (Noorbakhsh, 1998: 591; Anand and Sen, 2000: 99-102). Moreover, the HDI index equalizes the weight of the indices' components. This methodology may lead to misinterpretation of the index because extreme values affect the resulting index's value. Besides, some researchers suggest that the index's dependency on three heterogeneous indices does not seem to be a productive method to indicate the development in general (Noorbakhsh, 1998: 591-592).

Recently, to overcome the income discarding limitation, the HDI report started to compare the national income per capita's rank with the HDI's rank for each country. This improvement gives the analysis of the HDI clearer view to study the performance of an economy.

\subsection{Macroeconomic Indicators}

This section lists various macroeconomic indicators which contribute to the calculation of the economic development indicators. One of the main macroeconomic indicators is price level analysis. Price level indicator represents the average level of prices in an economy at a given time. Moreover, price level is affected by factors like unemployment, interest rates and a country's economic growth (Becsi, 1994:27-39). Economic environment factors affect price levels of goods and services, which have an impact on consumers' expectations of price levels.

Further, Becsi (1994: 27-39) highlighted that price levels have an impact on economic development. He pointed out how crucial it is to maintain stable price levels especially in turbulent economic environments. It is noteworthy that indicators such as interest rates, unemployment rates, inflation, and GDP growth are essential in maintaining stable price levels. Exposure to price levels may contribute to the consumers' welfare. Better understanding of price levels could arm marketers and policymakers with tools to enhance the society' welfare.

Additionally, measurements of price levels involve the use of consumer price index (CPI) and producer price index (PPI). The use of implicit price deflator for GDP is a better indicator of the price rank in financial prices as it shows shocks at a wider variety. On one hand, CPI considers the basket of goods consumed and paid for by urban individuals (Becsi, 1994:27-39). On the other hand, CPI takes into consideration the consumption of imported goods while the GDP deflators deal with locally produced products. PPI measures prices that producers charge for products used to make other goods like materials or finished goods.

Another important macroeconomic indicator is inflation rate. Inflation illustrates the continuous rise in prices of the same goods and services within a period. Higher rates of inflation refer to an exhausted economy, whereas controlled levels of inflation mark a boomed economy (Mankiw, 2013:101). Thus, it is helpful to study the inflation indicator with other indicators to have a more complete picture. Besides, inflation diminishes consumers' purchasing power and creates significant socio-economic and political consequences, (Smith, 2013:3). High rates of inflation may undermine and interfere with a country's social, economic, and political structure. Continuous inflation causes frustrations to millions of citizens who struggle with rising prices that they cannot control. Inflation also raises the cost of borrowing which hits investment (Mankiw, 2013:101-102). High and 
increasing inflation rates affect public deficits as the governing bodies are not able to issue debt. According to Fertig (1975), inflation undermines the part system by encouraging demagoguery. Inflation promotes a political environment which opposes the public demand and undermines citizen's political rights.

Targeted rate of inflation is important to hold the aggregate demand at healthy levels. However, deflation may significantly harm the economy by lowering consumers' spending and lowering the aggregate demand growth. For example, when prices drop, consumers expect that prices will fall in the future. Therefore, they may decide to delay their purchases for that reason. A controlled inflation rate reduces the real value of debt and allows prices to adjust and goods to attain their real price. Moreover, it allows relative wages to adjust. On the other hand, moderate inflation rates help the economic growth and may mark that the economy as healthy (Mankiw, 2013:117-120).

Further key macroeconomic indicator is unemployment rate. The unemployment level is the percentage of the unemployed workforce at a given time to total labor force. Unemployment rates help understand the overall present performance of an economy (Mankiw, 2013:178-179). It provides a measure of labor supply, labor input, a structure of unemployment, and the degree to which the available resources are being used. Unemployment rate helps in human resources development planning and policy formulation.

Unemployment rates have severe effects on economic development. High and steady unemployment rates lead to negative impacts on the long-term development of an economy. Additionally, unemployment leads to resources wastage, generation of redistributive pressures and distortions, higher poverty, reduced labor mobility, and leads to social unrest and conflicts (Mankiw, 2013:200).

Lastly, a vital macroeconomic indicator is the government expenditure. An increase in government expenditure would increase the aggregate demand in the economy. This increase in aggregate demand would lead to growing output and employment (Mankiw, 2013:313-314). Furthermore, Wu et al. (2010:804) indicate that government expenditures are helpful to economic output despite of how government size and economic growth are measured. Their results suggest that government expenditure caused economic growth in the short and long terms (Loizides and Vamvoukas, 2005). Thus, studying government intervention through its expenditures could explain the economic growth in a specific country.

\subsection{The Economic Development Indicators Summary}

The main approaches that have been used to indicate economic development in a specific economy or period are the GDP growth rate, real GDP per capita growth rate, human capital development, macroeconomic indicators and citizens' well-being. The economic expansion discussion is generally perceived to be an expression of various views. Moreover, to judge the economy's performance, various indicators should be reviewed to obtain an indepth analysis. This analysis supports decisions' making as well as setting out crucial policies to develop strong short-term and long-term plans. 


\section{REVIEWING THE ECONOMIC DEVELOPMENT IN SYRIA BEFORE THE CONFLICT}

In January 2011, Syrian president Bashar Assad answered in an interview with The Wall Street Journal that he did not expect Syrians to join the public protests which were sweeping through the Arab World at the time. He admitted that there had been economic difficulties for many Syrians and that steps towards political reforms had been hesitant and indecisive. However, few weeks after the interview, the protests started to spread, and Assad was in trouble. In reality, long-standing political and economic problems drove the country towards instability. When Assad came into power in 2000, there has been a small political shift towards greater political participation in the country. Nevertheless, this shift was quickly inverted, and Assad returned to the authoritarian policy of his father. Economically speaking, although Assad was meant to lead the country to liberalization, his policies mainly helped to empower a network of associate capitalists who are loyal to the administration. Indeed, two main factors played significant role in spreading the protests. The first factor is the lack of political freedom while the second is the miserable economic conditions symbolized in high unemployment rates, poverty and corruption (Cohen 2016: 9-12).

This section proceeds by reviewing and exploring data from the World Bank database better to understand the economic performance in Syria before the conflict. Also, the following section paves the way to answering whether the economic performance before the conflict could predict the conflict. To the end of answering this paper's question, cross country comparison is carried out in section 3.4. Moreover, GDP per capita growth (annual $\%$ ), Government Expenditure (\% of GDP), Inflation, Consumer Price Index (annual \%), Unemployment (\% of total labor force), and Human Development Index (HDI) are used to analyze the economic development situation in Syria before the conflict. In addition, all statistics have been benchmarked against the middle-income countries according to "World Bank" classification" in which Syria is classified. This analysis has been performed for the period between 1960 and 2010. Lastly, the last part will summarize the governance situation in Syria before the conflict to assess the role of administration in the economic performance as presented in the analysis.

\subsection{Syria's GDP Per Capita Growth Rate Analysis}

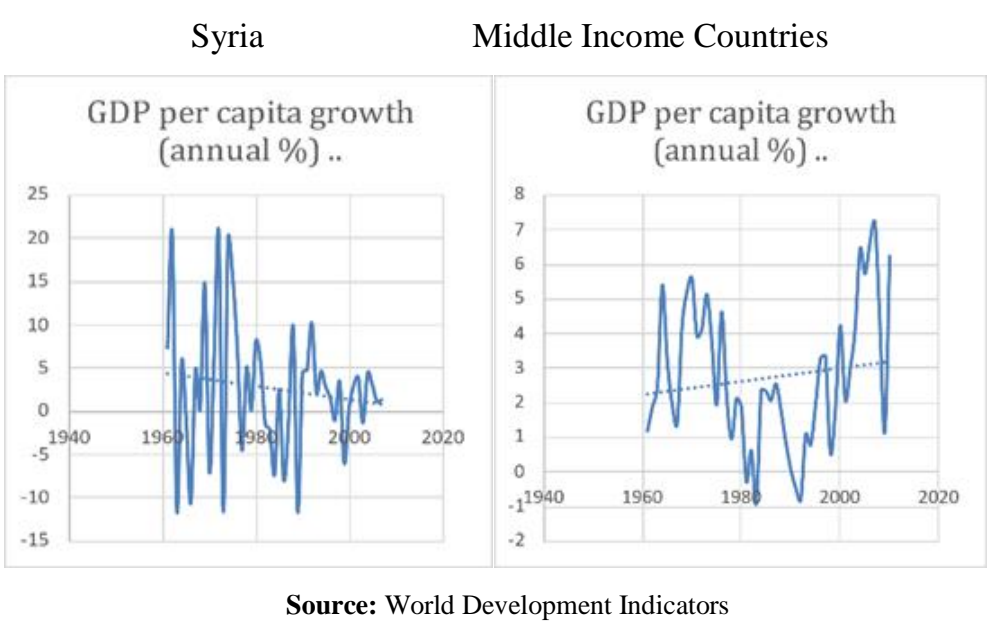

Figure 1: GDP per capita annual growth before 2010

\footnotetext{
*The middle-income countries are defined as: The world's Middle-Income Countries (MICs), which are defined as having a per capita gross national income of US\$1,026 to $\$ 12,475$ (2011) are a diverse group by size, population, and income level. Middle income countries are home to $75 \%$ of the world's population and $62 \%$ of the world's poor. See: https://www.worldbank.org/en/country/mic/overview .
} 
Figure 1 depicts that the annual growth of the GDP per capita in Syria trends downwards in the period before 2010 while it seems trending upwards in the middle-income countries for the same period. Moreover, the GDP annual growth in Syria is highly fluctuating in comparison with the middle-income countries. As mentioned earlier, the decrease in Syria's GDP per capita maybe noted as a fall back in the country's wealth which is reflected on the citizens situation. Also, the GDP per capita describes the country's economic productivity, which means that the cost of gaining income outweighs the outcome for this period. It, also, may reflect the shrinking of domestic income taking into account the increase in Syria's population.

To reach more robust analysis, this study will further explore the possible reasons behind the growth of GDP per capita trend over years. According to official government data, GDP growth averaged around 2.46\% during 1992-2006. This was close to the population growth of $2.45 \%$ on average over the same period. Therefore, the two averages suggest no real growth per capita (Marzouk, 2013: 39-40). Moreover, the rate of economic growth rather declined from an average of 8.5\% during the period 1990-1996 to an average of 2.9\% between 1997 and 2004 (Khaddam, 2013: 74).

On a sectoral growth level, there was a considerable growth in the services sector whereas the contribution of the production sector declined significantly. For instance, the contribution of the production sector was at $48.1 \%$ in 1992 before falling to $40.6 \%$ in 2010 (Marzouk, 2013: 39-40). This highlights that the structure of the Syrian economy is heading towards being an economy that is not based on knowledge, technical production and knowledge transfer. Nevertheless, while the growth in contribution of the services sector was only 5\% between 1990 and 1996, it was 30\% for the period 1997-2004. Besides, the industrial sector's contribution growth was $31 \%$ for the period 1990-1996 compared to $-16 \%$ for the period between 1997 and 2004 (Khaddam, 2013: 75). This implies that the downward trend in GDP per capita growth may be attributed to the decrease in contribution of high value-added sectors. Still, this finding may become crystal clear after reviewing the private investment.

Additionally, the private investment was also trending to decline before the conflict. For instance, the investment's share of GDP was at 28\% in 1980 and then dropped to $19 \%$ in 1991. After that, it fluctuated in the range of 17-22\% for the period 2000-2010. This shows the instability and uncertainty of the investment environment as well as the lack of investors' optimistic expectations to invest in Syria (Marzouk, 2013: 41). Furthermore, the tax evasion wasted about $40 \%$ of the GDP in 2002, which translates into approximately $\$ 21$ billion. Although the private sector constitution is about $60 \%$ of all economic activities, its contribution in taxable income was only $15 \%$. Besides, a high volume of savings had been lost due to the weak banking sector in Syria (Khaddam, 2013: 83).

Finally, the drop in GDP per capita describes the low level of the country's economic productivity. To clarify, reviewing the Syrian Economy Competitiveness Report issued in 2007 in cooperation with an official Syrian body, Syria was ranked 80th out of 131 countries. The report underlined 56 points of weaknesses for Syria. For instance, the waste of public funds, lack of government transparency, weak monitoring and accountability systems, spending on education, high inflation rate, low quality of the educational system, low quality of management colleges and schools, availability of training and research locally, the impact of foreign investment legislation, weak role of investment, the lack of procedures for establishing projects, the burden of customs procedures, high rate of brain immigration, the low level of investor protection, the weak technological utilization of local companies, the low quality of scientific research institutes, a tiny portion spending on scientific research, the weak creativity, the resistance to the delegation behavior, and others were the most 
critical points which are hitting the growth of GDP in Syria (Khaddam, 2013: 84-92). Moreover, the institutional weakness in managing the economic performance is reflected in weakness in productivity. For example, during the period from 1963 to 2010, the productivity of the Syrian worker did not exceed $75 \%$, despite the tremendous development in the world. This explains the very poor growth in capital accumulation, underemployment and waste in resources. Further, corruption and mismanagement of economic resources were also reflected in the size of the losses incurred by the public sector in a government report issued in 2008, which were estimated at about $\$ 8$ billion (Saifan, 2013: 117-119).

\subsection{Syria's Government Expenditure Analysis}

Figure 2 below presents the government expenditures which supposedly aimed at supporting the aggregate demand to generate economic growth in the short run.

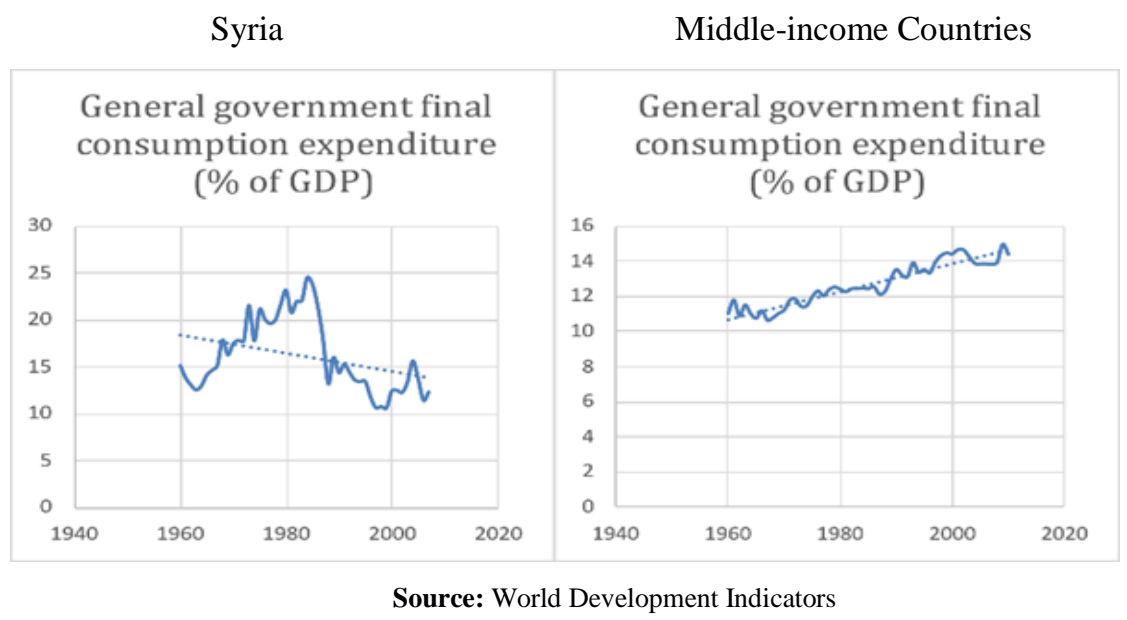

Figure 2: General Government Final Consumption Expenditure (\% of GDP)

Examining Figure 2 reveals that although there was an increase in the rate of government expenditure before 2000, these expenditures started to decrease again from 2004 to 2010. Moreover, the government final consumption rate trends to decrease after 1984 particularly.

At the beginning of sixties in the last century, the Syrian government's contribution to the GDP increased to $70 \%$ in 1970 in comparison to only $30 \%$ in 1963 . After Hafez alAssad came into power, he was convinced of the important role of the private sector to achieve economic growth. However, this conviction was associated with a fear from fueling the desire of capitalist class in more power. Consequently, he worked to expand the contribution of the private sector in a controlled and planned manner. It allowed a new class of businessmen to create wealth in close alliance with power. This could be illustrated by the fact that the private sector's contribution in the GDP was only $30 \%$ at the beginning of his presidency and then reached the level of 37\% after 10 years. According to official statistics, the private sector employed 70\% of the workforce in Syria by the end of 1980s. At the end of 1990s, the private sector's contribution in GDP rose to 60\%, and the government's contribution in GDP declined from $70 \%$ at the end of 1960s to $40 \%$ at the end of Hafez alAssad's rule. There was a little progress in some government policies after 2000. Yet, government expenditures returned to decline again after 2004, and the private sector's share of GDP reached $70 \%$ again (Saifan: $97-114$ ).

Arguably, expanding the involvement of privet sector in the economic recovery should be reflected in the economic indicators. However, the tax evasion, government 
corruption and the alliance of businessmen with authority have all contributed to bad economic performance. For instance, the overall poverty rate in Syria increased to $33.6 \%$ in 2007 from $30 \%$ in 2004. Also, the share of wages in the GDP decreased from $40.5 \%$ to $33 \%$ during the 2004-2007 era. This means that the income distribution was shifted from the middle class to the wealthy class in the country. Another example would be the official Household Income and Expenditure Survey carried out in 2009. The survey showed that the average household expenditures are approximately 30 thousand Syrian pounds, while the average of wages was only 9 thousand. Besides, more than $68 \%$ of Syrian families spend less than 30,000 Syrian pounds a month. The Syrians were using external transfers and asset sales to coexist with their poor living conditions (Marzouk, 2013: 54-56).

Likewise, the collapse in government expenditure was reflected in declining health services. Health services used to be provided to citizens for free. However, that service has deteriorated with the decline in provisions allocated to health services in the budget. Consequently, citizens have suffered from the higher burden of healthcare costs in general, needless to mention the poor service in public hospitals. The introduction of certain laws has made it more difficult for Syrian families from the middle-class or below. An example of these laws is the law which cancelled health insurance for government sector employees' families. As a result, more Syrian citizens faced more shrinkage in benefits, the thing that weakened the standards of living in general (Marzouq, 2013: 49-52).

\subsection{Syria's Inflation Rates Analysis}

To analyze the economic development in Syria, studying the inflation rate discloses very useful information. To this end, Figure 3 presents the inflation rate trends for the period of before the last Syrian crisis in 2011. Figure 3, also, benchmarks inflation rates in Syria against the middle-income countries level. Figure 3 shows that the rate of inflation is fluctuating but tends to steadily increase most of the time. Inflation rates had lots of deviations in some periods such as 1973, (1980-1981), (1985-1987), 1990 and (2006-2008). These years mark a very unusual times for the Syrian nation. In comparison with the middleincome countries, it can be inferred that the inflation rate in these countries trends to decrease from $(13-11 \%)$ to moderate level in (3-5\%). This marks Syria amongst the highest inflated economies within the middle-income countries.

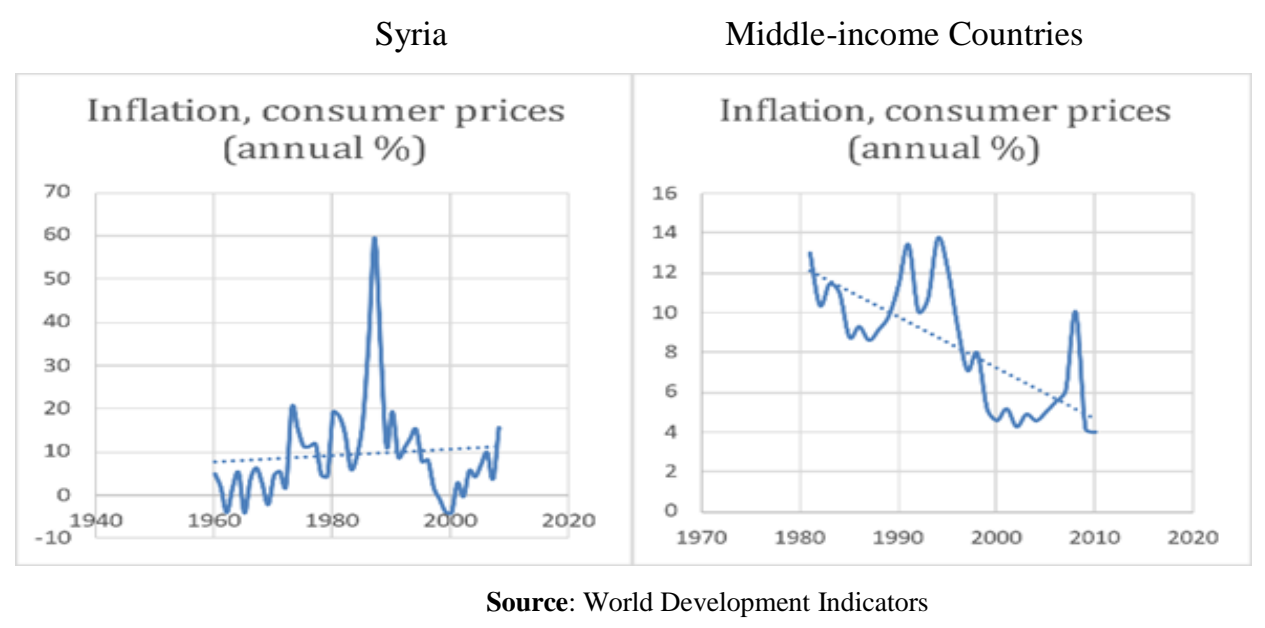

Figure 3: Inflation Consumer Prices (Annual \%) 


\subsection{Syria's Unemployment Analysis}

Put differently, by analyzing the unemployment figures for the same period, Figure 4 clearly highlights that the unemployment rates in Syria were increasing especially after 1980. The rate of unemployment for the period of (1980-2000) was in the range between 4$7 \%$. Then, it was $7-11 \%$ after 2000. Remarkably, contrary to what Figure 4 indicated for Syria, it showed that the unemployment rate in the middle-income countries trended to decrease. The average unemployment rate for those countries was at the range of 3-5\%.

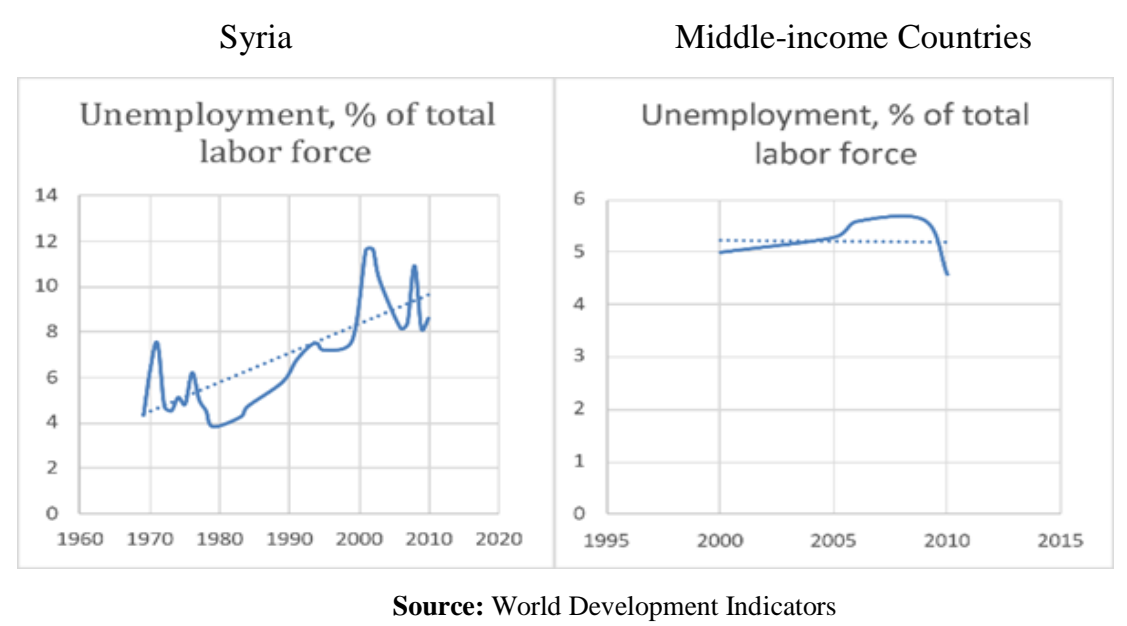

Figure 4: Unemployment, \% of Total Labor Force

The low level of economic growth along with continuous population growth, led to a rise in unemployment over years. The Syrian economy was incapable of creating job opportunities due to many structural defects and the absence of an effective economic plan. Although official labor surveys may not be accurate due to the growth of the unofficial sector which in turn account for about $39.2 \%$ of the labor force in 2001 . The unemployment figures showed a significantly higher upward trend. In addition, the high rate of the labor force migration to the population is an indication of the inability of the economy to create job opportunities for more members of the workforce. This was reflected in the increase in the percentage of migration among Syrians from an average of $3.4 \%$ of the total population in the early 1990s to an average of 10.2\% between 2000 and 2005 (Marzouq, 2013: 52-54).

\subsection{Syria's Human Development Index Analysis}

Finally, Figure 5 depicts that the human development index in Syria is stable during the studied period. Also, we could consider this stability in main two period, from 1990 to 2000 and after 2000. It is worthy to note that the HDI level in Syria started to pick momentum in the year 2003-2004 and then overturned immediately after that. Syria has been classified in the medium human development group of countries according to HDI. 


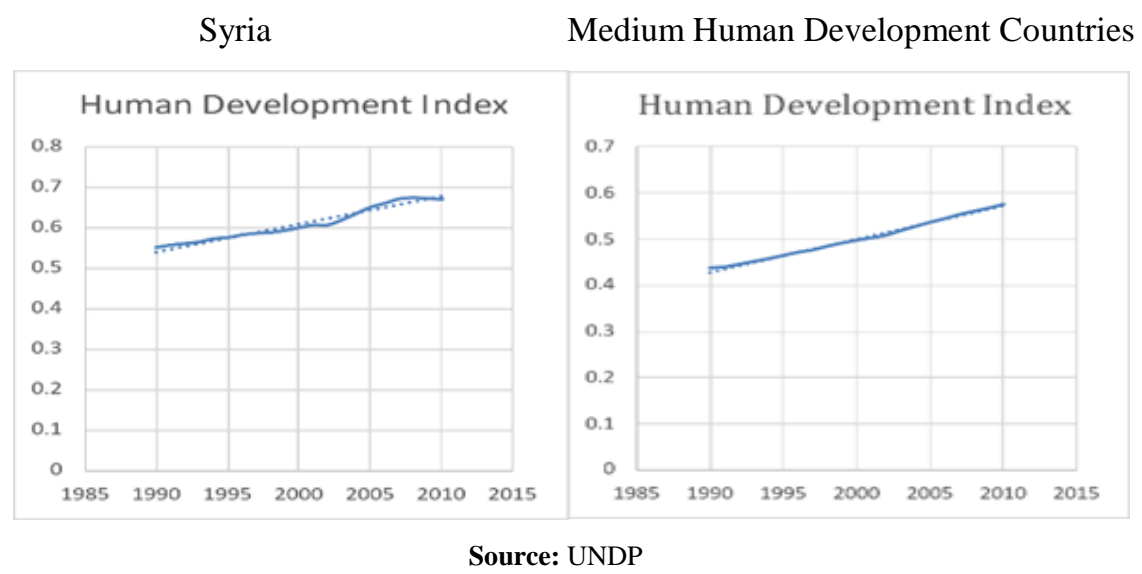

Figure 5: Human Development Index

In fact, the illiteracy rate in Syria increased from $15.9 \%$ in 2005 to $16.9 \%$ in 2009. In addition, the schooling rate decreased from $4 \%$ to $1 \%$ during the mid-1980s and 2000. All this was reflected in the human capital growth rate which changed from an average of $5 \%$ during the first half of 1980 s in the last century to $3.8 \%$ during the second half of $1980 \mathrm{~s}$. Then, it was at $2.1 \%$ during the first half of the 1990s. It continued its decline journey not only to reach $0.7 \%$ between 1995 and 2005, but also to plummet again to $0.2 \%$ until the year 2010. These figures may be supported by the increase in poverty rates in Syria during the aforementioned period and the deterioration in job creation indicator as well. Another example of the drop in human capital growth rate is the average age of marriage among girls. This average age has increased to 25.3 years, which may describe the difficulties faced by society members to enter into marriage in general (Marzouq, 2013: 47-48).

On the higher education level, it was clear that the number of students wanting to study is greater than the absorptive capacity of the universities in the country. This is evidenced by the tough prerequisites imposed by universities on students who want to study at the universities. Accordingly, the authorities gave a green light to open new private universities, which absorbed only $5 \%$ of the total number of interested students. It is noteworthy to emphasize that this $5 \%$ determines the ability of a small fraction of the population to bear the burdens of private education. Consequently, HDI level in Syria indicates the poor quality of education and its failure to keep pace with competition in the labor market. This has forced the newly opened banks in Syria to bring in their technical employees from outside Syria (Marzouq, 2013: 49).

\subsection{Summary of Syria's Economic Development}

The above analysis goes in line with the other historical analyses of Syria's economy in the literature. Syria's economic development over the years could be summarized in the following section. Syria's economy showed relatively high growth levels in the 1960s and 1970s. Through the 1980s, Syrian economic growth was diminishing. This diminishing economy is accompanied with the same old economic policies in the previous period. In addition, the aforementioned economic policies have led to the expansion of corruption. They, also, have set more pressure from the government to undermine the citizens' political rights under the control of Assad's Father. After that, in 1990s the economic situation has improved due to better oil revenues. Besides, there was a trend to liberalize the country to rescue the economy from dropping further, needless to mention the problematic conditions of 80s. The economy improved in 1990s, particularly, in the first half of this decade. 
At the beginning of the new millennium, the country's elites hoped that the new president could bring some openness to the economy and, therefore, to the country. However, over the years, the reforming actions took an ostensible form and were emptied of meaning by the influence of a group of capitalists allied with the administration (Cohen, 2016: 13-16). Moreover, poverty and biased regional development rose severely in the second half of the 2000s. Rural poverty signs were higher than urban. Also, the rural communities did not benefit from the economic reformations while the agriculture sector was affected by a multi-year drought. At the same time, the population growth and employment opportunities did not grow in parallel. For instance, the unemployment rate was highest among the age group 15-24 levelled at 22\% percent in 2006 (Gobat and Kostial, 2016: 3-6).

During earlier periods of Assad's father control, Syrians had initiated many social movements in 1980-1982 which were paralyzed with the authority's socio-economic behavior (Britannica, 2020). However, the last conflict in 2011 was the most influential. This acuteness may be due to the booming waves of protests in neighboring Arab countries and improved communication means.

\section{CONCLUSIONS}

This paper explores whether the economic indicators were able to predict the last conflict in Syria in 2011. The analysis in this work examines the economic development indicators and the available data about Syria from the World Development Indicators dataset. The investigation of the available data suggests that the indicators of economic development in Syria could help in predicting the social disturbances. Specifically, the GDP per capita was steepening over the study period. This fall back in the country's wealth explains the country's economic productivity decrease over time. The GDP growth was outweighed by the population growth which points to no real growth per capita. Furthermore, the contribution of the production sector in the GDP dropped dramatically between 1992 and 2010. The deterioration in the Syrian economy could be attributed to the shrinkage in the contribution of high value-added sectors. Likewise, the tax evasion in the private sector, which accounts to $60 \%$ of all economic activities in Syria, and the government corruption have exhausted the Syrian economy.

Additionally, the uncertainty of the investment environment may interpret the diminishing investment's share of GDP for the period 2000-2010 compared to 1980. Demotivated investors have chosen not to invest in Syria due to lack of transparency and corruption. Moreover, the percentage of government expenditure from GDP slipped in Syria to a very alarming levels during the studied period. This emphasizes that the role of the Syrian government in generating income was very reluctant before the conflict. This finding is backed up by the fact that, after 2004, the private sector's contribution in the GDP plunged more than $130 \%$ since 1970 . As a result, more Syrian citizens faced more fade in benefits, which paved the way to a much higher poverty rate leveled at 33\% in 2007.

Nonetheless, inflation and unemployment rates were not at healthy levels, where inflation exceeded $10 \%$ on average while unemployment shoot up to $11 \%$ during the studied period. On the other hand, employment and price stability play a significant role in sustainable development, economic growth and social cohesion. The high unemployment rate may be responsible for the sharp increase in the average migration of the total population between 2000 and 2005. Finally, the HDI index seems to have worsen or at least did not improve. This in itself as well as the drop in the illiteracy rate, which reached to $16.9 \%$ in 2009 , recommends that the country is progressing negatively in terms of development. The 
human capital growth rate lost grounds in 2010 with a decline of more than $2500 \%$ since 1980. Therefore, this clearly suggests that there are no government plans whatsoever to improve Syria's human resources during the analyzed period. That conclusion could also be extended to all other indicators as well.

To summarize, the economic indicators studied in this paper were all worrying. Typically, the public seemed to be under extreme economic pressure to the extent that they may participate in any movement which may help releasing that pressure. These findings support that the economic development indicator were at alarming levels before 2011, which paved the way to the 2011's conflict in Syria. Furthermore, this study's findings endorse that it is vitally important for policymakers in any country to follow up the economic development indicators to set an effective development plan in their countries which will in turn enhance stability and economic welfare of their societies. Besides, this study highlights the role economic movements could play in peacebuilding in any country which had fallen into a conflict. In other words, economic and political welfare could be the sought-after key to resolve any potential or current conflict. Finally, the role of political rights and civil liberties in helping policymakers to set more sustainable economic development plans is an issue to be further examined in future research.

\section{REFERENCES}

Acemoglu, D., Johnson, S., \& Robinson, J. (2013). Why Nations Fall: The Origins of Power, Prosperity and Poverty. Profile Books LTD, 529 Page.

Aitken, A. (2019). Measuring Welfare Beyond GDP, National Institute Economic Review, 249(1), R3-R16.

Anand S. \& Sen A. (2000). The Income Component of the Human Development Index, Journal of Human Development, 1(1), 83-106, DOI:10.1080/14649880050008782.

Becsi, Z (1994). Indicators of the General Price Level and Inflation, Federal Reserve Bank of Dallas Economic Review, 27-39.

Berber M. (2015). İktisadi Büyüme ve Kalkınma, DERYA Kitabevi: Trabzon.

Bhargava, A., Jamison, T. D., Lau, L. \& Murray, C. (2001). Modeling the Effects of Health on Economic Growth, Journal of Health Economics, 20(3), 423-440.

Bhargava, A. (2001). Nutrition, Health, and Economic Development: Some Policy Priorities, Food and Nutrition Bulletin, 22(2), 173-177.

Bloom, D. E., Canning, D. \& Sevilla, M. (2004). The effect of Health on Economic Growth: A Production Function Approach, World Development, 32(1), 1-13.

Bobkov, V. N. \& Veredyuk, O. V. (2013). Impact of Employment Instability on Socio-economic Position of Employees, The Economy of Region, 35-43, doi:10.17059/2013-4-3.

Brueckner, M., Dabla-Norris, E. \& Gradstein, M. (2014). National Income and its Distribution. IMF Working Papers.

Byrd, M. W., (2011). Education, Economic Growth, and Social Stability: Why the Three Are Inseparable, The Hidden crisis: armed conflict and education; EFA global monitoring report, https://unesdoc.unesco.org/ark:/48223/pf0000190743.

Cohen E. (2016). From Arab Spring to Economic Winter - Examination of the Relationship Between Politics and Economics as Evident in the Syrian Civil War During 2011-2015, Journal of International Studies, 9(1), 9-26, DOI: 10.14254/2071-8330.2016/9-1/1.

Council of Economic Advisers Issue Brief. (2015). A Better Measure of Economic Growth: Gross Domestic Output (GDO). 
Cravino, J.\& Haltenhof, S. E. (2017). Real Exchange Rates, Income Per Capita, and Sectoral Input Shares, (No. w23705), National Bureau of Economic Research.

Delalibera, B.R. \& Ferreira, P.C. (2019). Early Childhood Education and Economic Growth. Journal of Economic Dynamics and Control, 98, 82-104.

Fayzi, S., Naderkhani, Z. \& Zolfaghari, A. (2015). An Analysis of Social Stability and Its Determining Factors among Rural Women in Iran, Quest Journals, Journal of Research in Humanities and Social Science, 3(5), 1-8, ISSN(Online): 2321-9467.

Fertig, L. (1975). The Political Costs of Price Inflation, Foundation for Economic Education, https://fee.org/articles/the-political-costs-of-price-inflation/ (Accessed Date: 14.12.2020).

German, D. \& Latkin, C.A. (2012). Social Stability and Health: Exploring Multidimensional Social Disadvantage. Journal of Urban Health, 89(1), 19-35.

Gobat, J. \& Kostial, K. (2016). Syria's Conflict Economy. IMF Working Papers, 16(123).

Ivic, M. (2015). Economic Growth and Development. Journal of Process Management - New Technologies International, 3(1), 55-62.

Khaddam, M. (2013). The economic basis of the Syrian crisis, The Revolution's Background: Syrian Studies, Arab Center for Research \& Policy Studies, Arabic Edition, pp 71-94.

Liu, A. (2016). Why Economic Development Matters? Brookings, https://www.brookings.edu/blog/the-avenue/2016/03/07/why-economic-developmentmatters/ (Accessed date:18.11.2020).

Loizides, J. \& Vamvoukas, G. (2005). Government Expenditure and Economic Growth: Evidence from Trivariate Causality Testing. Journal of Applied Economics, 8(1), 125-152, DOI: 10.1080/15140326.2005.12040621.

Mankiw, N.G (2013). Macroeconomics. Worth Publishers, Eighth Edition.

Marzouk S. (2013). Lost Development in Syria, The Revolution's Background: Syrian Studies. Arab Center for Research \& Policy Studies, Arabic Edition, 35-70.

Nafziger, E. W. (2006). Economic Development, Cambridge, England: Cambridge University Press.

Nolan, B., Roser, M. \& Thewissen, S. (2016). GDP Per Capita Versus Median Household Income: What Gives Rise to Divergence Over Time? LIS Working Paper Series.

Noorbakhsh F. (1998). The Human Development Index: Some Technical Issues and Alternative Indices, Journal of International Development J. Int. Dev. 10, 589-605.

Saifan, S. (2013). Income Distribution Policies and Their Role in the Social Explosion in Syria, The Revolution's Background: Syrian Studies. Arab Center for Research \& Policy Studies, Arabic Edition, 95-146.

Smith K. (2001). Comparing Economic Performance in the Presence of Diversity, Science and Public Policy, 28(4), 267-276.

Smith, Todd (2013). Food Price Spikes and Social Unrest in Africa, Climate Change and African Political Stability Program, https://www.files.ethz.ch/isn/165516/researchbrief\%20no\%2011 final.pdf (Access date: 10.01.2021).

Son H. (2009). A Cross-Country Analysis of Achievements and Inequities in Economic Growth and Standards of Living, ADB Economics, Working Paper Series, No 159.

Stiglitz, J. (2017). Income Inequality and Social, Economic, and Political Instability, World Government Summit, Dubai, Feb 13, 2017.

Stockhammer, E., Hochreiter, H. \& Steiner, K. (1997). The index of Sustainable Economic Welfare (ISEW) as an Alternative to GDP in Measuring Economic Welfare: The Results of the Austrian (revised) ISEW Calculation 1955-1992". Ecological Economics, 21, 19-34. 
Stockwell E. (1960). The Measurement of Economic Development, Economic Development and Cultural Change, Volume 8, Number 4, Part 1.

Tabassam, A.H., Hashmi, S.H. \& Rehman, F.U. (2016). Nexus Between Political Instability and Economic Growth in Pakistan, Procedia-Social and Behavioral Sciences, 230, 325-334.

Tsertseil, J.S., Kookueva, V.V. \& Laptev, S.V. (2017). Assessment of the Relationship Between Economic Growth and Investment in Higher Education. Journal of Economic \& Management Perspectives, 11(4), 305-311.

UNDP (United Nation Development Program) (2020), http://hdr.undp.org/en/content/humandevelopment-index-hdi , (Access date: 12.12.2020).

World Development Indicator, https://databank.worldbank.org/source/world-developmentindicators? savedlg=1\&l=en\# (Access Date: 12.12.2020).

Wu, S.Y., Tang, J.H \& Lin, E.S. (2010). The Impact of Government Expenditure on Economic Growth: How Sensitive to the Level of Development? Journal of Policy Modeling, 32(6), 804-817, ISSN 0161-8938, https://doi.org/10.1016/j.jpolmod.2010.05.011 